\title{
The role of morphodynamics in predicting coastal flooding from storms on a dissipative microtidal beach with SLR conditions: Cartagena de Indias (Colombia)
} Jairo E. Cueto $^{1}$, Luis J. Otero ${ }^{2}$, Silvio R. Ospino-Ortiz ${ }^{2,3}$, Alec Torres-Freyermuth ${ }^{4}$

$5{ }^{1}$ Research Group in Natural and Exact Sciences - GICNEX. Department of Natural and Exact Sciences. Universidad de la Costa. Barranquilla (Atlántico), Colombia.

${ }^{2}$ Research Group in Geosciences - GEO4. Department of Physics and Geosciences, Universidad del Norte. Barranquilla (Atlántico), Colombia.

${ }^{3}$ Centro de Investigación de Ingeniería de Cormagdalena - CIIC. Barranquilla (Atlántico), Colombia.

$10{ }^{4}$ Laboratory of Engineering and Coastal Processes - LIPC, Engineering Institute. Universidad Autónoma de México (UNAM). Sisal (Yucatán), México.

Correspondence to: J. Cueto (jcueto7@cuc.edu.co)

Abstract. The main object of the present work was to study the role of morphodynamic changes in the flooding of a dissipative beach with microtidal regime, considering the simultaneous and individual effects of erosion and flooding in scenarios of long-

15 term mean sea level rise. For this analysis, we selected a sector of the Colombian Caribbean coast with great touristic, historical, economic, cultural and social importance, namely, Cartagena de Indias; specifically, the beach of Bocagrande. By simultaneously considering erosion and flood processes associated with highly energetic waves, the study facilitates the construction of more precise models for assessing threats to coastal zones. SWAN and XBeach nested models were carried out in order to predict morphological changes and flooding during selected cold fronts and hurricanes that affected Cartagena

20 de Indias; those numerical models were calibrated using field campaigns data (pre- and post-storm). The results of this research indicate that flooding on microtidal dissipative beaches under extreme wave conditions should be approached by considering morphodynamics, because ignoring them can underestimate flooding by $\sim 15 \%$. The erosion and flood effects are intensified by sea level rise, resulting in the most unfavorable condition when extreme events are contemporaneous with high tides.

\section{Introduction}

25 The impact of extreme storms on a coast has important consequences for coastal communities associated with loss of life and injuries, as well as significant direct and indirect economic losses (Kron, 2013; Bertin et al., 2014; Sills et al., 2008). In highly urbanized coastal areas, such as the coastal area of Cartagena de Indias (Colombia), where different types of infrastructure (homes, hotels, and businesses) are located near the coast, such storms generally damage or destroy exposed elements. These effects are the integrated consequences of two storm-induced coastal hazards, flooding and erosion (Sanuy and Jiménez, 2019; Guimaraes et al., 2015). In this context, an adequate quantification of these hazards is an essential part of risk management (e.g., Ciavola et al., 2011; Jiménez et al., 2018; Plomaritis et al., 2018; Harley et al., 2017; Sanuy and Jiménez, 2019). The use of process-oriented numerical models to forecast storm-induced morphodynamic changes in given scenarios is a widespread and widely accepted methodological practice (e.g., Roelvink et al., 2009; McCall et al., 2010; Dissanayake et al., 2014; Annette et al., 2020). 
Predicting flooding associated with storm impacts accompanied by intense erosion can pose a problem on multiple scales, governed by complex interactions between a great variety of hydrodynamic processes and of sediment transport (Wu et al., 2011; Christensen et al., 2013; He et al., 2015). Among the most important factors for the prediction are: (i) increase in sea level associated with climate change, which increases the exposure of the coast during extreme events; (ii) beach erosion; (iii) flooding during and after a storm (Elsayed and Oumeraci, 2016).

The traditional approach to the study of flooding and erosion caused by storms has been to investigate the two coastal threats separately, i.e., flooding (e.g., Ruju et al., 2014; Guimaraes et al., 2015; Medellín et al., 2016; Lerma et al. 2017; Fiedler et al., 2018) and erosion (Schambach et al., 2018). Particularly for the area of the Colombian Caribbean coast, works have focused on evaluating the threat of flooding from extreme waves, without considering changes in beach morphology produced by the studied storm (Andrade et al., 2013; Orejarena et al., 2019). However, recent studies have examined the impact of both threats simultaneously, basically using the eXtreme Beach Behavior (XBeach) model as a tool (Stockdon et al., 2014; de Santiago et al., 2017; Sanuy and Jiménez, 2019; Enríquez et al., 2019). This model solves hydrodynamic processes associated with gravity (Sea - Swell) waves (refraction, shoaling and breaking), infragravity (Igrav) waves, setup induced by waves and currents, and morphodynamic processes such as dune erosion and sediment transport (Roelvink et al., 2009).

Extreme wave events on the Colombian Caribbean coast are associated with hurricanes and cold fronts (Ortiz, 2007; Ortiz et al., 2013; Otero et al., 2016; Cueto and Otero, 2020). The meteo-marine event that most affected the central coast of Colombia in the last decade was the cold front of March 2009, which collapsed a 200-m section of the old Puerto Colombia pier (Ortiz et al., 2014). Although Colombia is in a fortunate location in the Caribbean regarding the trajectory of hurricanes, it is not exempt from the consequences of a devastating passage. Hurricanes such as Joan (1988) (Ortiz, 2008), Lenny (1999) (Ortiz, 2009), and more recently Matthew (2016) (Cueto and Otero, 2020) and Iota (2020), among others, have impacted the Colombian Caribbean coasts, causing flooding and erosion along the coastline. After an analysis of 1980-2014 satellite images and field measurements, Rangel-Buitrago et al. (2015) estimated that $48.3 \%$ (1182 km) of the Caribbean Colombian coast had 60 serious erosion problems. Only 33.2\% (812.6 km) could be considered stable and the remaining $18.4 \%$ (450.5 km) showed accretion. The erosive dynamics found along the northern coasts of Colombia have been influenced by different factors, among which are extreme wave events (Rangel-Buitrago et al., 2015; Otero et al., 2016). In the particular case of the coastal area of Cartagena de Indias, the coastline experienced setbacks of as much as 50 meters because of an anomalous succession of extreme events (hurricanes and cold fronts) between January 2010 and January 2011 (Bernal et al., 2016). This forced the 65 execution of an emergency procedure for recovery of the beaches using hydraulic fill. Moreover, flood events due to extreme waves caused by dry-season cold frontal passages affecting the city of Cartagena de Indias have become increasingly frequent (Andrade et al., 2013; Otero et al., 2016). This is because it has been established that the rate of rise in mean sea level in this 
region was $5.6 \mathrm{~mm} /$ year during the period 1950-2009 (Torres and Tsimplis, 2012), which has aggravated the impact of the aforementioned phenomena in the region (Orejarena et al., 2019).

Per the above, the main object of the present work was to study the role of morphodynamic changes in the flooding of a dissipative beach with microtidal regime, considering the simultaneous and individual effects of erosion and flooding in scenarios of long-term mean sea level rise. For this analysis, we selected a sector of the Colombian Caribbean coast with great touristic, historical, economic, cultural and social importance, namely, Cartagena de Indias. By simultaneously considering erosion and flood processes associated with highly energetic waves, the study facilitates the construction of more precise models for assessing threats to coastal zones and identification of the implications of not including the effects of morphodynamic changes on the flooding. This will enable the design of plans with more robust criteria for the management of irrigation and mitigation actions, in order to protect the population and infrastructure from threats by the sea.

\section{Data and methods}

80 The methods used and their respective steps are detailed in the following subsections.

\subsection{Description of study area}

The study area is comprised of Bocagrande Beach (Figure 1), which forms a section of the coastline of the city of Cartagena de Indias in the central Colombian Caribbean. Regarding morphology, Bocagrande has a dissipative profile (Figure 2), with an offshore slope of $0.3 \%$ and foreshore slope of $1.8 \%$. Furthermore, it is composed of fine sands with grain sizes between

850.08 and $0.42 \mathrm{~mm}$ (Conde et al., 2017a; b). Within the study domain of Bocagrande, there are six groins that extend between 50 and $100 \mathrm{~m}$ within the area of breakers, being oriented perpendicular to the coast. The tide in the study area fluctuates between 20 and $30 \mathrm{~cm}$, classifying Bocagrande as a microtidal beach (Restrepo et al., 2012; Restrepo et al., 2016).

Detailed bathymetries were determined along with control profiles in field campaigns developed before and after a succession of cold fronts between November 2014 and February 2015. In these campaigns, hydrodynamic data were also acquired, using

90 a cross-shore arrangement of four current meters (S5, S4, S3 and S2) and a pressure sensor (S1). A detailed description of the sections referring to these field campaigns is given in Cueto \& Otero (2020).

Owing to its location in the Caribbean, the hydro-climatology of the study area is also influenced by the migration of the Intertropical Convergence Zone (ITCZ) (Poveda, 2004; Pérez et al., 2018). The ITCZ is an area of the globe where the trade winds of the northern and southern hemispheres converge, generating a low-pressure belt around the equator that oscillates

95 seasonally. The Colombian Caribbean is governed climatically by this movement (Poveda, 2004), producing a bimodal regime with two dry seasons (December-March and June-July) and two wet seasons (April-May and August-November). During dry periods, winds tend to be stronger; from December to March, the trade winds from the north predominate, while between June and July the prevailing winds are from the southeast. In contrast, the rainy months have weaker winds. 
https://doi.org/10.5194/nhess-2021-210

Preprint. Discussion started: 19 July 2021

(c) Author(s) 2021. CC BY 4.0 License.
Natural Hazards and Earth System Sciences

Discussions

The influence of the trade winds in times of drought produces waves with strong energy, the northeast direction being the component with the highest probability of occurrence (32\%) (Ortiz, 2012; Restrepo et al., 2012). With less probability ( 15\%), waves arrive from the east-northeast, north and north-northeast directions. Waves originating outside these directions are generated by local winds and have a low probability of occurrence in the area.
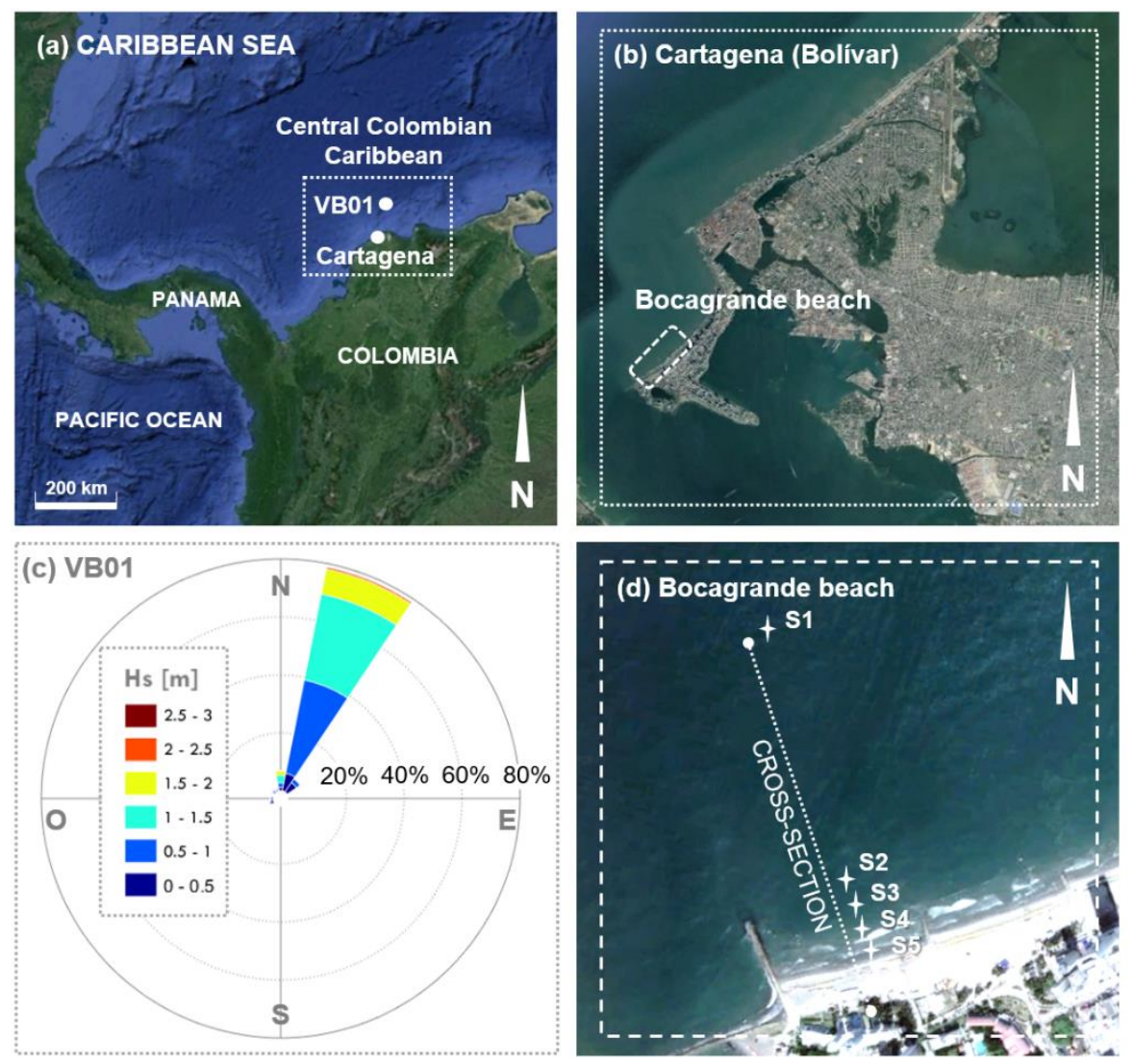

Figure 1: Location of study area: (a) location of Cartagena in the Colombian Central Caribbean and Virtual Buoy

01 [VB01] $\left(1^{\circ} 40^{\prime} 1.12^{\prime \prime} \mathrm{N}, 7^{\circ} 30^{\prime} 0.00^{\prime \prime} \mathrm{W}\right)$; (b) location of Bocagrande Beach in Cartagena de Indias; (c) wave rose extracted from VB01; (d) instrumental setup during field campaigns. Map base images retrieved from $\odot$ Google Earth and modified by the authors. 

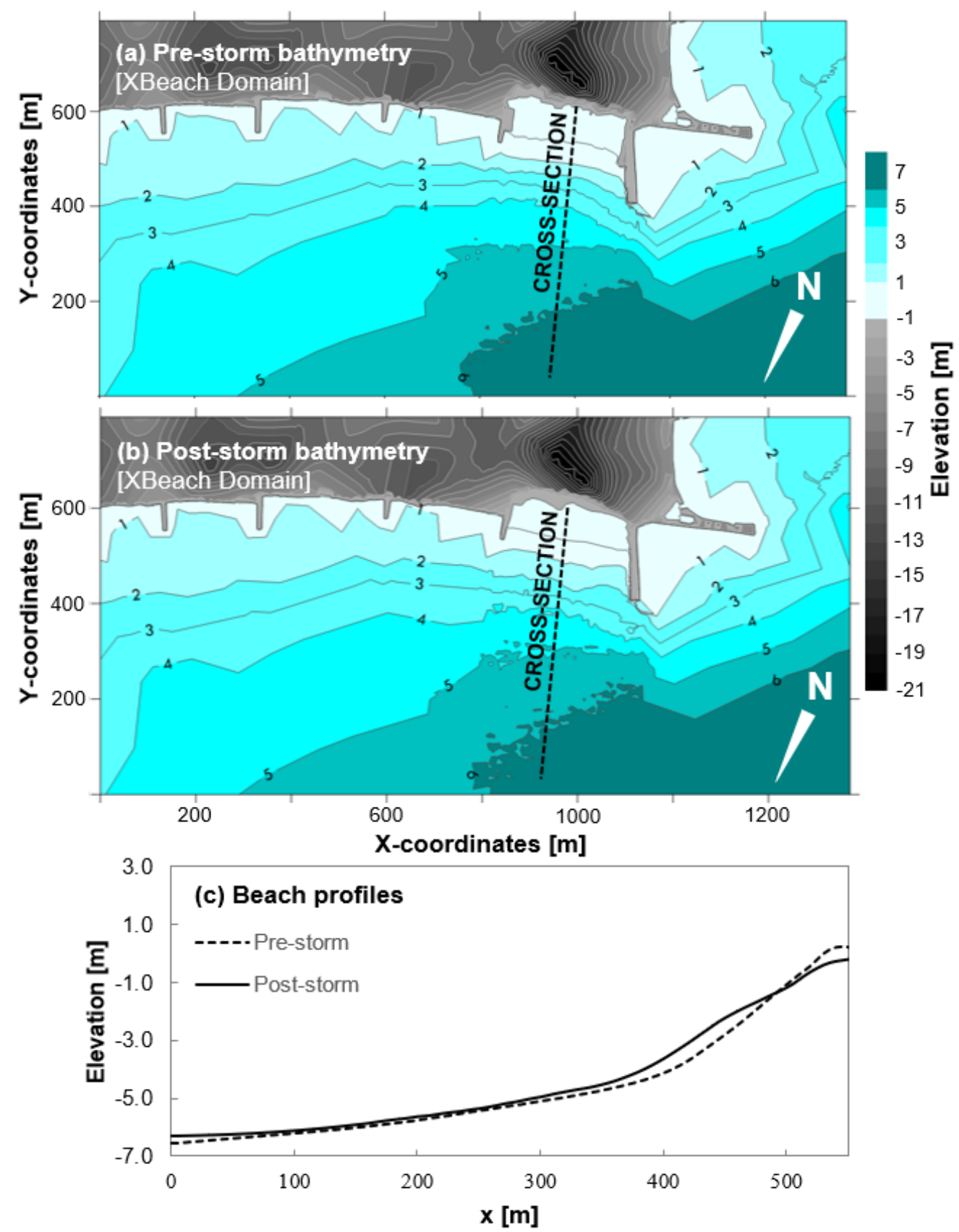

Figure 2: (a) Pre-storm detailed bathymetry; (b) post-storm detailed bathymetry; (c) pre- and post-storm beach profiles at

Bocagrande (Cartagena de Indias).

\subsection{Selected events}

In order to identify extreme wave events in Bocagrande, wave series were extracted from the Virtual Buoy 01 (VB01) in the central Colombian Caribbean, near the coast of Cartagena de Indias (Figure 1a). These reanalysis series were obtained from a 
NOAA database that used the third-generation model WAVEWATCH III as a source (Chawla et al. 2013). This database was adjusted to the conditions of the Colombian Caribbean by Vega (2018). It is well known that the wave reanalysis information tends to underestimate wave heights associated with extreme events. However, with the adjustment of Vega (2018), errors do not exceed $5 \%$ for significant wave height calculations.

Subsequently, the series extracted for each area of interest were compared with the exact dates on which hurricanes and cold fronts occurred in the Colombian Caribbean over the last four decades (Ortiz, 2012; Ortiz et al., 2013; Bernal et al., 2016; Otero et al., 2016). We thereby constructed a detailed inventory of extreme wave events in the study area. From this, we selected case studies for subsequent hydro-morphodynamic modeling. As selection criteria, we considered events that strongly affected the Cartagena de Indias area, analyzing the energy contents, impacts, and proximity to the coast of each storm (Ortiz, 2012; Ortiz et al., 2013; Bernal et al., 2016; Otero et al., 2016). The inventory of hurricanes and cold fronts was integrated with conditions of sea level rise (SLR) for the coming decades at Bocagrande Beach, as predicted and discussed by Orejarena et al. (2019). This was done to investigate the combined effects of erosion and flooding following the impact of storms in future scenarios with higher sea levels.

The inventory with some of the most important hurricanes and cold fronts affecting Cartagena over the last 40 years is shown in Table 1. Among the data from VB01, there are noteworthy maximum wave heights of 2.76 and $3.53 \mathrm{~m}$. These values were recorded during the passage of Hurricane Lenny (1999) and the cold front of December 2017, respectively. Lenny traversed the study area as a tropical storm, producing extreme waves during approximately two days. In contrast, the cold front of December 2017 persisted longer in the study area, generating an increase in wave heights over five days. Both events were selected to evaluate the morphodynamic response of Bocagrande Beach.

Analogously, the extreme events of 2010 reported by Bernal et al. (2016) were chosen for case study. According to Bocagrande's historical records, this set of storms generated unprecedented recessions along the coastline (50 $\mathrm{m}$ in one year) and was particularly associated with the 2010 Atlantic hurricane season (Bernal et al., 2016). We especially emphasize three cold fronts during March 2010, which most influenced the erosive processes of that year (25-30 m retreat in less than a month).

140 Between the first and the second cold front of that month there was a period of six days with moderate waves. Between the second and third cold front there were moderate waves over eight days. SLR was considered for future scenarios following the projections of Orejarena et al. (2019) for the Cartagena de Indias area. These projections were prepared according to data from the Integrated Climate Data Center of the University of Hamburg. The aforementioned authors projected a SLR of 0.11 (2025), 0.24 (2050), 0.38 (2075), and $0.52 \mathrm{~m} \mathrm{(2100)} \mathrm{at} \mathrm{Bocagrande.} \mathrm{The} \mathrm{selected} \mathrm{events} \mathrm{from} \mathrm{which} \mathrm{the} \mathrm{case} \mathrm{studies} \mathrm{were}$

145 formulated are shown in italics in Table 1. 
Table 1: Analyzed storms from VB01 (Bocagrande) wave series. Maximum significant wave height (Hs), peak period (Tp), and mean direction (Dm) are displayed. * Denotes duration of effect across study area.

\begin{tabular}{rcccc}
\hline Hurricane & $\begin{array}{c}\text { Duration } \\
(\text { days })^{*}\end{array}$ & $\mathrm{H}_{\mathrm{s}}(\mathrm{m})$ & $\mathrm{T}_{\mathrm{p}}(\mathrm{s})$ & $\mathrm{D}_{\mathrm{m}}\left(^{\circ}\right)$ \\
\cline { 3 - 5 } Joan (1988) & 2 & 1.31 & 4.98 & 259.92 \\
Bret (1993) & 2 & 1.90 & 8.77 & 17.81 \\
Cesar (1996) & 2 & 1.48 & 9.38 & 17.69 \\
Mitch (1998) & 2 & 1.35 & 6.62 & 258.61 \\
Lenny (1999) & 2 & 2.76 & 7.91 & 316.09 \\
Sandy (2012) & 2 & 1.70 & 6.63 & 260.37 \\
Matthew (2016) & 3 & 2.29 & 12.03 & 192.07 \\
\hline Cold fronts & & $\mathrm{H}_{\mathrm{s}}(\mathrm{m})$ & $\mathrm{T}_{\mathrm{p}}(\mathrm{s})$ & $\mathrm{D}_{\mathrm{m}}\left(^{\circ}\right)$ \\
\hline Cold front (March, 2009) & 5 & 2.49 & 8.96 & 26.76 \\
Cold front A (March, 2010) & 5 & 2.66 & 7.51 & 357.24 \\
Cold front B (March, 2010) & 3 & 1.34 & 5.90 & 24.76 \\
Cold front C (March, 2010) & 6 & 1.60 & 8.81 & 25.87 \\
Cold front (December, 2017) & 5 & 3.53 & 9.14 & 35.79 \\
\hline
\end{tabular}

\subsection{Numerical modelling}

This section outlines the numerical modeling approach to determine wave propagation from deep waters, using the Simulating WAves Nearshore (SWAN) numerical model (Boij \& Holthuijsen, 1999) and its subsequent nesting with the XBeach model (Roelvink et al., 2009) to represent the hydrodynamics and morphodynamics of the Cartagena de Indias coastal zone.

\subsubsection{From deep waters to the coast: Wave propagation using $S W A N$}

Propagation from deep waters during the selected events was determined by the SWAN model, originally developed by Booij \& Holthuijsen (1999). The wave series of the events were propagated from the location of virtual buoy VB01 in deep waters (Figure 1a) to $\sim 1 \mathrm{~km}$ from the Bocagrande coast (collocated with the offshore boundary of the computational domain used in XBeach).

SWAN was calibrated for the study area by Cueto \& Otero (2020), taking into account in situ wave data measured in field campaigns before and after storms, following parameters established by Conde et al. (2017a). Table 2 shows the computational domain used for SWAN modeling of Cartagena, and Table 3 the error parameters calculated by Cueto \& Otero (2020) for model performance at Bocagrande. 
Table 2: SWAN and XBeach computational domain for Bocagrande Beach.

\begin{tabular}{rcc}
\hline \multicolumn{1}{c}{ GRID } & SWAN & XBeach \\
\hline Cell size [m] & 100 & $5-3-1$ \\
X [nodes] & 334 & 790 \\
And [nodes] & 280 & 1570 \\
Area $\left(\mathrm{km}^{2}\right)$ & 935.2 & 1.24 \\
\hline
\end{tabular}

Table 3: SWAN error parameters for Bocagrande (Cueto \& Otero, 2020).

\begin{tabular}{lcc}
\hline \multirow{2}{*}{ Parameter } & \multicolumn{2}{c}{ Bocagrande } \\
\cline { 2 - 3 } & Pre-storm & Post-storm \\
\hline Bias & -0.05 & 0.01 \\
$\mathrm{r}^{2}$ & 0.91 & 0.87 \\
Willmott & 0.96 & 0.95 \\
\hline
\end{tabular}

\subsubsection{Beach morphodynamics: XBeach}

A representation of hydrodynamics, flooding and morphodynamic response to extreme wave events, considering SLR scenarios at Bocagrande, was realized using XBeach (Roelvink et al., 2009).

175 XBeach is an open-source numerical model originally developed by the University of Delft to simulate hydrodynamic and morphodynamic processes on sandy beaches, using a domain of kilometers and the timescale of storms. This includes hydrodynamic processes such as (Sea - Swell) SS wave transformation (refraction, shoaling and breaking), Igrav wave (generation, propagation and dissipation), wave-induced setup and non-stationary currents, and overwash and flooding. The morphodynamic processes that XBeach solves include suspended sediment and bottom transport, dune erosion, bottom updating, and breaching (Roelvink et al., 2009). The model can be used in three modes, i.e., phase-averaged, surfbeat and nonhydrostatic. In the present study we used the surfbeat mode.

The model includes solvers for NLSWE and morphodynamics, so its application can be extended to simulate coastal flooding together with erosion processes, using a single mesh calculation for both modules. This approach offers the advantages of simulating the mutual interaction between hydrodynamics and morphodynamics.

The computational domain defined for hydro-morphodynamic modeling of Bocagrande Beach using XBeach (Figure 2) covers an area of $1.24 \mathrm{~km} 2(1.57 \mathrm{~km}$ alongshore and $0.79 \mathrm{~km}$ cross-shore). The domain is distributed on a mesh of rectangular cells 
with variable sizes, ranging from $5 \mathrm{~m}$ wide in the areas furthest from the coast to $1 \mathrm{~m}$ in the closest areas. Characteristics of

the computational domain used with XBeach are shown in Table 2.

The model was calibrated based on experimental data (topo-bathymetric and hydrodynamic) collected during field campaigns pre- and post-storm. Cueto \& Otero (2020) described this calibration for the study area in detail, following the two-step methodology presented by Nederhoff (2014) and aspects from more extensive calibrations carried out by Ranasinghe et al.

195 (2011) and Luijdendijk et al. (2017) (Table 4). The latter calibration procedures also include morphological processes on timescales greater than those of storms. Table 4 shows a summary of the calibration procedure results by Cueto \& Otero (2020). The best morphologic representations were obtained when using a facua (factor ua) parameter of 0.35 and 0.45 , combined with a Chezy friction coefficient of $45 \mathrm{ml} / 2 / \mathrm{s}$. According to the classification elaborated by van Rijn (2004), which includes a qualitive scale for morphological representation based on different Brier Skill Scores (BSS) (BSS = 1, perfect representation; $\mathrm{BSS}=0$, poor representation), the model approximation was qualified as "Excellent".

Table 4: XBeach morphodynamic parameters and performance for Bocagrande.

\begin{tabular}{ccccc}
\hline Profile & facua & Chezy $\left[\mathrm{m}^{1 / 2} / \mathrm{s}\right]$ & BSS & Qualification \\
\hline A & 0.05 & 45 & 0.41 & Reasonable \\
B & 0.20 & 45 & 0.67 & Good \\
C & 0.35 & 45 & 0.89 & Excellent \\
D & 0.45 & 45 & 0.80 & Excellent \\
\hline
\end{tabular}

For the hydro-morphodynamic modeling with XBeach, the study cases shown in Table 5 were established. The sediment transport module in XBeach was turned on and off for each case study. In this way, the influence of erosive processes on flooding was checked. The models included a non-erodible layer to simulate the hard structures present on Bocagrande Beach. 
Table 5: Selected study cases for evaluation through numerical modeling of Bocagrande Beach. * Indicates that between cold fronts there was a six-day period of average wave conditions between $A$ and $B$, and eight days between $B$ and $C$. ** Indicates that the additional effect of a $\mathbf{+ 0 . 2 5} \mathbf{m}$ high tide was included, without considering the storm surge.

\begin{tabular}{|c|c|c|c|c|c|c|c|}
\hline $\begin{array}{l}\text { Case } \\
\text { study }\end{array}$ & Storm & & $\operatorname{SLR}(\mathrm{m})$ & $\mathrm{H}_{\mathrm{s}}(\mathrm{m})$ & $\mathrm{T}_{\mathrm{p}}(\mathrm{s})$ & $\operatorname{Dm}\left({ }^{\circ}\right)$ & Duration (days) \\
\hline A1 & Lenny 1999 & 0.00 & Current conditions & 2.76 & 7.91 & 316.09 & 2 \\
\hline A2 & Lenny 1999 & 0.11 & (2025) & 2.76 & 7.91 & 316.09 & 2 \\
\hline A3 & Lenny 1999 & 0.24 & (2050) & 2.76 & 7.91 & 316.09 & 2 \\
\hline $\mathrm{A} 4$ & Lenny 1999 & $0.24 * *$ & $(2050)$ & 2.76 & 7.91 & 316.09 & 2 \\
\hline B1 & $\begin{array}{l}\text { Cold fronts } \\
(A+B+C) 2010\end{array}$ & 0.00 & Current conditions & $\begin{array}{l}\text { (A) } 2.66 \\
\text { (B) } 1.34 \\
\text { (C) } 160\end{array}$ & $\begin{array}{l}7.51 \\
5.90 \\
8.81\end{array}$ & $\begin{array}{l}357.24 \\
24.76\end{array}$ & $5(\mathrm{~A})+3(\mathrm{~B})+6(\mathrm{C})^{*}$ \\
\hline $\mathrm{B} 2$ & $\begin{array}{l}\text { Cold fronts } \\
(A+B+C) 2010\end{array}$ & 0.11 & (2025) & $\begin{array}{l}\text { (C) } 1.60 \\
\text { (A) } 2.66 \\
\text { (B) } 1.34 \\
\text { (C) } 1.60\end{array}$ & $\begin{array}{l}8.81 \\
7.51 \\
5.90 \\
8.81\end{array}$ & $\begin{array}{c}25.87 \\
357.24 \\
24.76 \\
25.87\end{array}$ & $5(\mathrm{~A})+3(\mathrm{~B})+6(\mathrm{C})^{*}$ \\
\hline B3 & $\begin{array}{l}\text { Cold fronts } \\
(A+B+C) 2010\end{array}$ & 0.24 & (2050) & $\begin{array}{l}\text { (A) } 2.66 \\
\text { (B) } 1.34 \\
\text { (C) } 1.60\end{array}$ & $\begin{array}{l}7.51 \\
5.90 \\
8.81\end{array}$ & $\begin{array}{c}357.24 \\
24.76 \\
25.87\end{array}$ & $5(\mathrm{~A})+3(\mathrm{~B})+6(\mathrm{C})^{*}$ \\
\hline B4 & $\begin{array}{l}\text { Cold fronts } \\
(A+B+C) 2010\end{array}$ & $0.24 * *$ & (2050) & $\begin{array}{l}\text { (A) } 2.66 \\
\text { (B) } 1.34 \\
\text { (C) } 1.60\end{array}$ & $\begin{array}{l}7.51 \\
5.90 \\
8.81 \\
\end{array}$ & $\begin{array}{c}357.24 \\
24.76 \\
25.87 \\
\end{array}$ & $5(\mathrm{~A})+3(\mathrm{~B})+6(\mathrm{C}) *$ \\
\hline $\mathrm{C} 1$ & Cold front 2017 & 0.00 & Current conditions & 3.53 & 9.14 & 35.79 & 5 \\
\hline $\mathrm{C} 2$ & Cold front 2017 & 0.11 & (2025) & 3.53 & 9.14 & 35.79 & 5 \\
\hline $\mathrm{C} 3$ & Cold front 2017 & 0.24 & (2050) & 3.53 & 9.14 & 35.79 & 5 \\
\hline $\mathrm{C} 4$ & Cold front 2017 & $0.24 * *$ & $(2050)$ & 3.53 & 9.14 & 35.79 & 5 \\
\hline
\end{tabular}

\section{Results}

This section presents the results of numerical modeling to evaluate the threat posed by the combined effect of erosion and flooding on the studied beach under extreme wave and SLR conditions.

225 Figures 3-6 show the maximum extent of flooding (with the transport module sediment on and off) and post-storm shorelines simulated by XBeach after the passage of storms with characteristics similar to Lenny 1999, the 2010 cold front succession and 2017 cold front, incorporating different SLR scenarios and using the current Bocagrande bathymetry. Figure 7 shows the control profile of Bocagrande Beach evaluated for different case studies with obtained beach retreats. Table 6 summarizes the most important results of each case study. 
https://doi.org/10.5194/nhess-2021-210

Preprint. Discussion started: 19 July 2021

(c) Author(s) 2021. CC BY 4.0 License.

(c) (†)

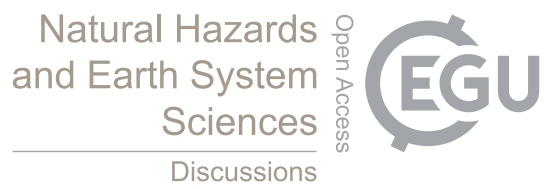

\section{$230 \quad 3.1$ Hurricane Lenny 1999}

In case study A1 (Figure 3a), the coastline retreat varied between 15 and $18 \mathrm{~m}$, with erosion more evident along beach sections between groins 3 and 4 and 4 and 5. In case studies A2 (Figure 3b) and A3 (Figure 3c), with SLRs of +0.11 and $+0.24 \mathrm{~m}$ respectively, the erosive processes became more aggressive, especially in the latter case. The coastline retreated between 19 and $24 \mathrm{~m}$ in the XBeach simulations for case A2, whereas in the most extreme scenario (A3), erosion was able to cause the

235 loss of as much as $32 \mathrm{~m}$ of beach in the most critical section (between groins 4 and 5). In Figure 7a, one sees changes in the Bocagrande control profile (which is in the most critical section) after storm simulation with various SLRs, indicating retreats of 15 (A1), 22 (A2) and $30 \mathrm{~m}(\mathrm{~A} 3)$.

The maximum flooding extent in all case studies was greater for simulations in which XBeach had the sediment transport 240 module activated (sed-on). With this module turned on, the maximum range of the water layer during the storm was 95,110 and $135 \mathrm{~m}$ for cases A1, A2 and A3, respectively. In cases A2 and A3 (both with sed-on) the results showed partial flooding in the urban area of Bocagrande, penetrating $31 \mathrm{~m}$ with the SLR conditions of 2025, and $41 \mathrm{~m}$ with the SLR of 2050 (measured from the first street located next to the beach). Flooding in the sed-off simulations did not extend beyond that boundary street. 
https://doi.org/10.5194/nhess-2021-210

Preprint. Discussion started: 19 July 2021

(C) Author(s) 2021. CC BY 4.0 License.

\section{Natural Hazards and Earth System \\ Sciences \\ Discussions}
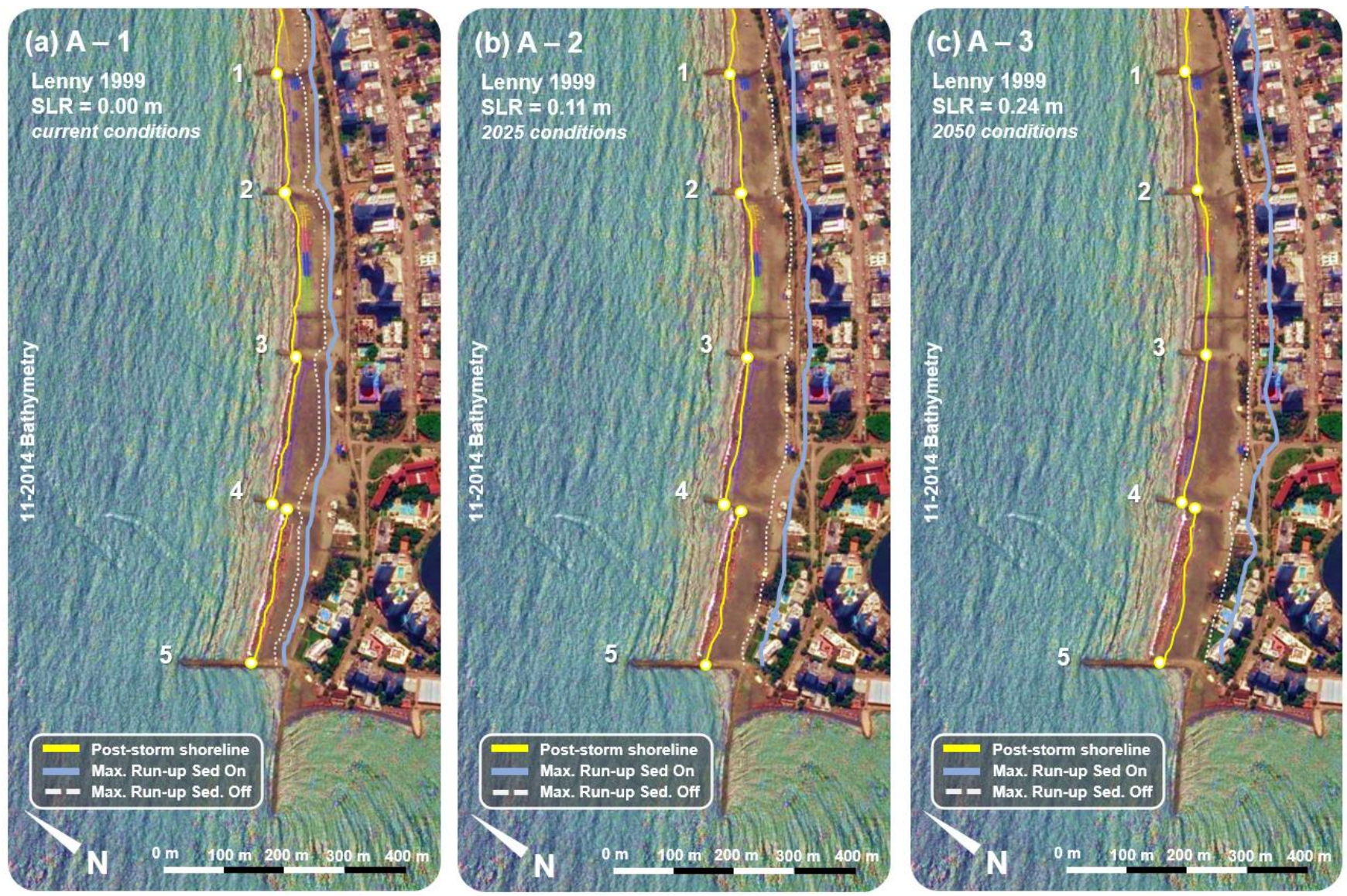

245 Figure 3: Maximum flood range (with sediment transport module on and off) and post-storm shorelines simulated by XBeach for a storm similar to Lenny 1999 with different SLR conditions. Map base images retrieved from (c) Google Earth and modified by the authors.

\subsection{0 cold fronts}

The results of case B1 (Figure 4a) indicate maximum retreats of nearly $30 \mathrm{~m}$ in the section between groins 4 and 5 . In the

250 remaining Bocagrande sections, erosion consumed an average $25 \mathrm{~m}$ of beach. Upon applying the 2025 SLR conditions in the model (Figure 4b), the losses of coastline began to exceed $35 \mathrm{~m}$ and the erosion was accentuated in every Bocagrande section. In the most severe case (B3) (Figure 4c), the retreats reached $\sim 50 \mathrm{~m}$, as occurred between groins 2 and 3 in the most critical transect. Figure 7b reveals variations in the control profile after the passage of cold fronts, showing beach losses of 28 (B1), 33 (B2) and $45 \mathrm{~m}(\mathrm{~B} 3)$.

Regarding maximum flood extent, XBeach calculated that with an SLR of $+0.24 \mathrm{~m}$ and a succession of cold fronts similar to that of 2010 (B3), the water line penetrated widely in the urban area of Bocagrande (96 m measured from the beginning of the first street with sed-on, and $67 \mathrm{~m}$ with sed-off). This particular case study was that with the greatest erosion and flooding in 
https://doi.org/10.5194/nhess-2021-210

Preprint. Discussion started: 19 July 2021

(C) Author(s) 2021. CC BY 4.0 License.

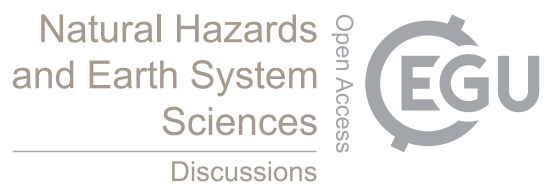

the analysis area. Measured from the shoreline, the maximum range of the water sheet with a non-static bottom was 109,141

and $184 \mathrm{~m}$ in cases B1, B2 and B3, respectively. In cases B1 and B2, flooding also occurred in the urban area when sed-on was used, with maximum intrusions up to $11 \mathrm{~m}$ in the first case and $50 \mathrm{~m}$ in the second (measured from the first street). With sed-off, the flood penetrated $94 \mathrm{~m}$ inland in case B1 (not exceeding the urban limit) and $113 \mathrm{~m}$ in B2 (both measured from the coastline).
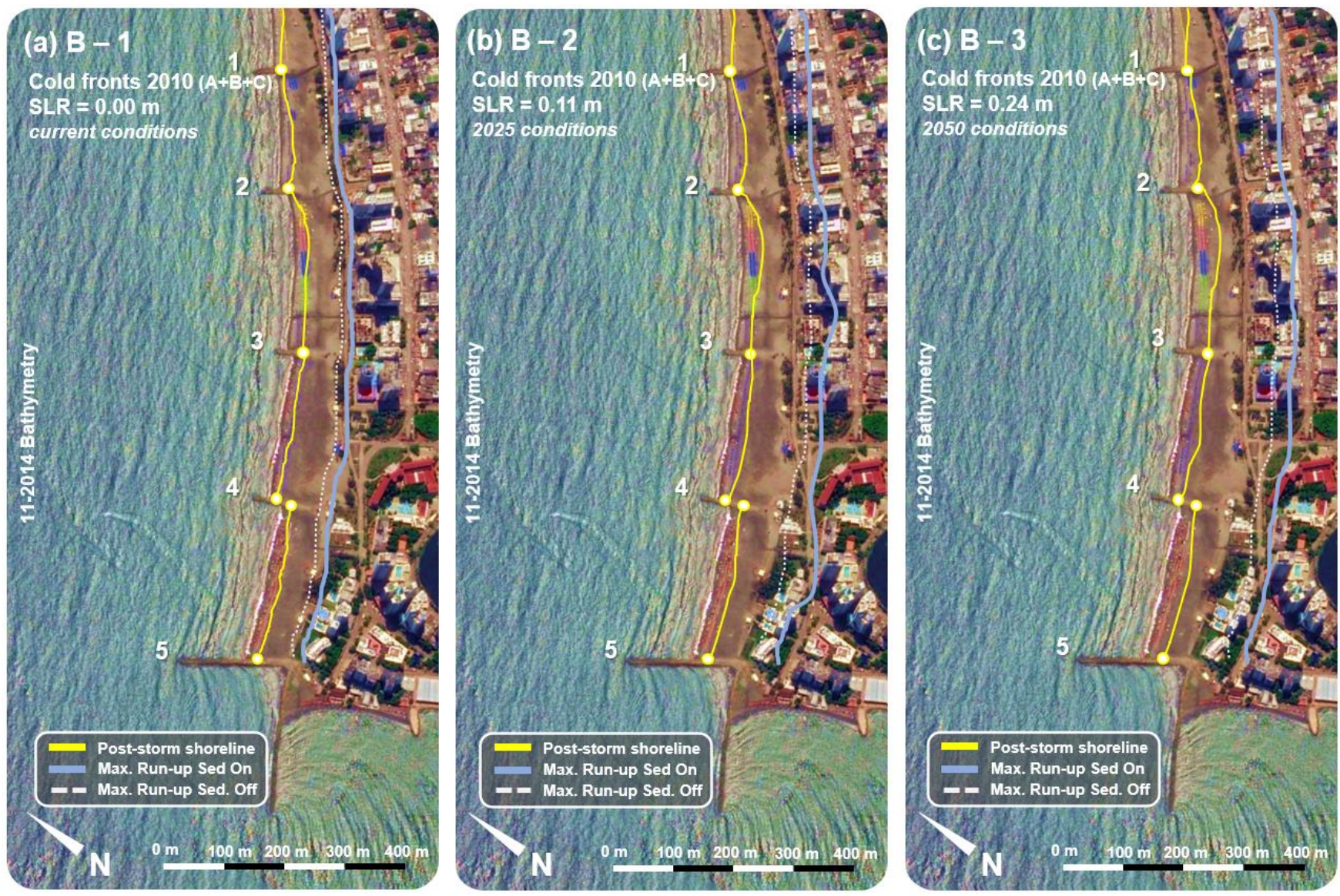

265 Figure 4: Maximum flood reach (with sediment transport module on and off) and post-storm shorelines simulated by XBeach for 2010 cold front succession with different SLR conditions. Map base images retrieved from $\subset$ Google Earth and modified by the authors.

\subsection{7 cold front}

From analysis of a storm similar to the cold front of 2017 with varying SLR conditions, the greatest coastline retreat calculated

270 by XBeach exceeded $30 \mathrm{~m}$. This was in the section between groins 2 and 3, after applying a SLR of $+0.24 \mathrm{~m}$ (case C3, Figure 5c). In cases $\mathrm{C} 1$ (Figure 5a) and C2 (Figure 5b), beach losses calculated by the model were smaller, 19 and $26 \mathrm{~m}$, respectively, in the sections where erosion was more severe. Figure $7 \mathrm{c}$ illustrates beach losses in the control profile after cold frontal passage, with retreats of $23(\mathrm{C} 1), 28(\mathrm{C} 2)$ and $34 \mathrm{~m}(\mathrm{C} 3)$. 
https://doi.org/10.5194/nhess-2021-210

Preprint. Discussion started: 19 July 2021

(C) Author(s) 2021. CC BY 4.0 License.

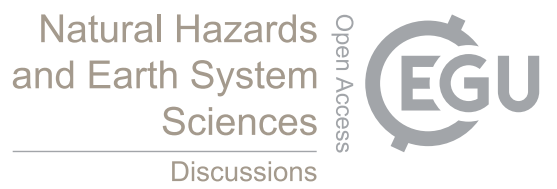

275 The flooding under current SLR conditions reached $97 \mathrm{~m}$ with sed-on and $88 \mathrm{~m}$ with sed-off, failing to reach the streets of Bocagrande. On the other hand, the maximum range of the water layer was $113 \mathrm{~m}$ (94 m with sed-off) under 2025 SLR conditions, and $148 \mathrm{~m}$ (119 m with sed-off) under SLR 2050 conditions. In cases C2 and C 3 with sed-on, the water penetrated 36 and $49 \mathrm{~m}$ beyond the beginning of the first street.
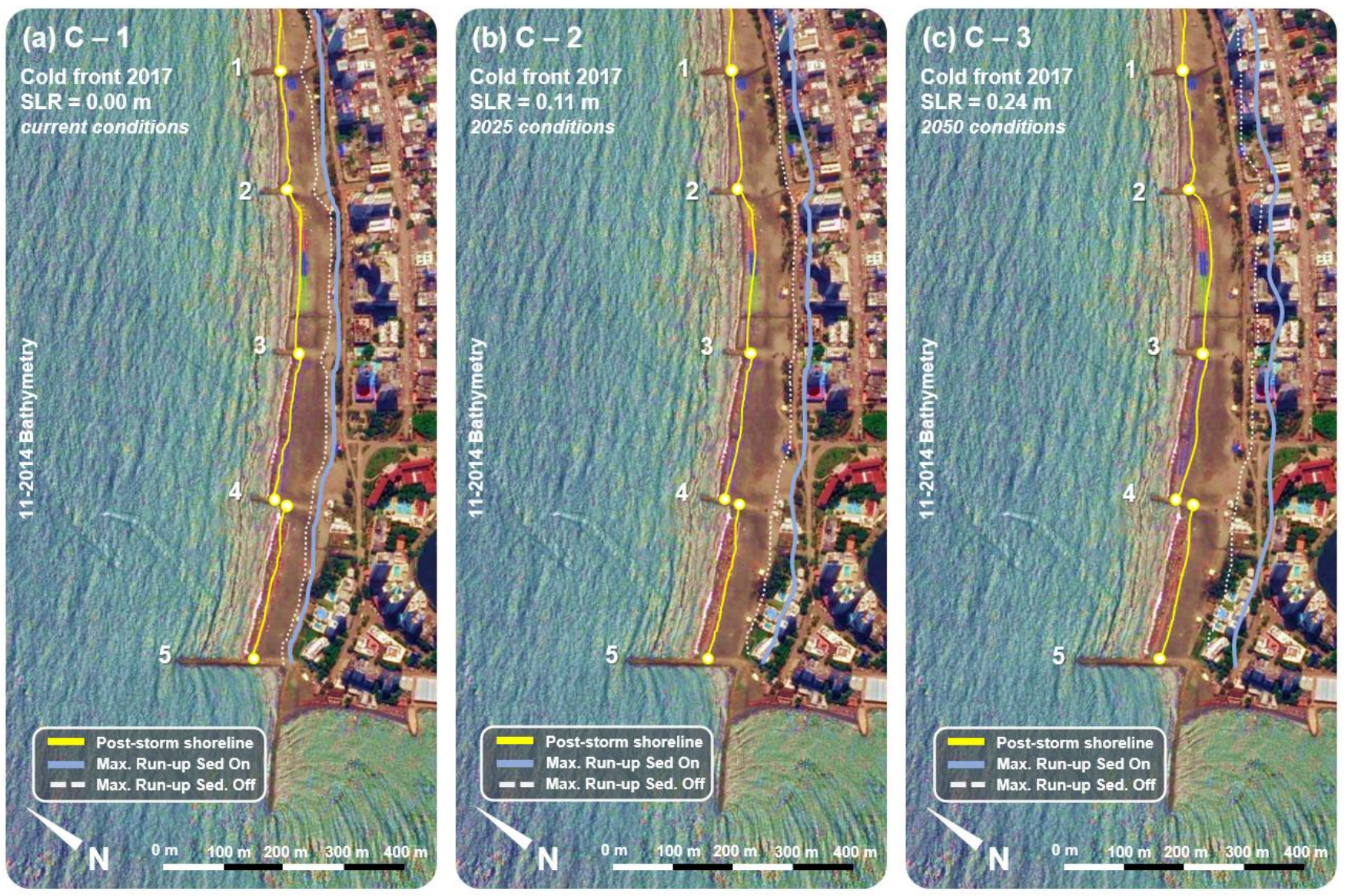

280 Figure 5: Maximum flood range (with sediment transport module on and off) and post-storm shorelines simulated by XBeach for a storm similar to 2017 cold front with different SLR conditions. Map base images retrieved from (C) Google Earth and modified by the authors.

\subsection{Extreme events: high tide $+0.25 \mathrm{~m}$}

In case study A4 (Figure 6a), which corresponds to Hurricane Lenny with a SLR of $+0.24 \mathrm{~m}$ plus high- tide effects $(+0.25 \mathrm{~m})$,

the coastline receded between 20 and $34 \mathrm{~m}$, erosion becoming more aggressive in beach sections between groins 3 and 4 and 4 and 5. In the case of the 2010 succession of cold fronts, including a SLR projected for the year 2050 and high tide (B4) (Figure 6b), erosion was severe, with beach losses up to and exceeding $50 \mathrm{~m}$ in most sections that comprise the XBeach computational domain. The results for the 2017 cold front with SLR of $+0.24 \mathrm{~m}$ and high tide (Figure 6c) indicate notable 
https://doi.org/10.5194/nhess-2021-210

Preprint. Discussion started: 19 July 2021

(C) Author(s) 2021. CC BY 4.0 License.

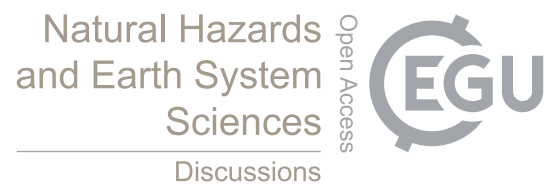

retreats of as much as $40 \mathrm{~m}$ in the beach sections between groins 2 and 3, 3 and 4, and 4 and 5 . Figure $7 \mathrm{~d}$ shows beach losses

290 in the control profile after the extreme events, with retreats of 31 (A4), 40 (B4) and $49 \mathrm{~m}$ (C4).

The results also show that the maximum flood extent occurred when erosive processes were included in XBeach. The sea produced inland flooding as far as 147, 199 and $157 \mathrm{~m}$ in cases A4, B4 and C4, respectively, with sed-on. Likewise, for all cases, in this section there was penetration of the sea into urban areas of Cartagena, reaching 52 (A4), 105 (B4) and $58 \mathrm{~m}$ (C4) as measured from the boundary street of the area.
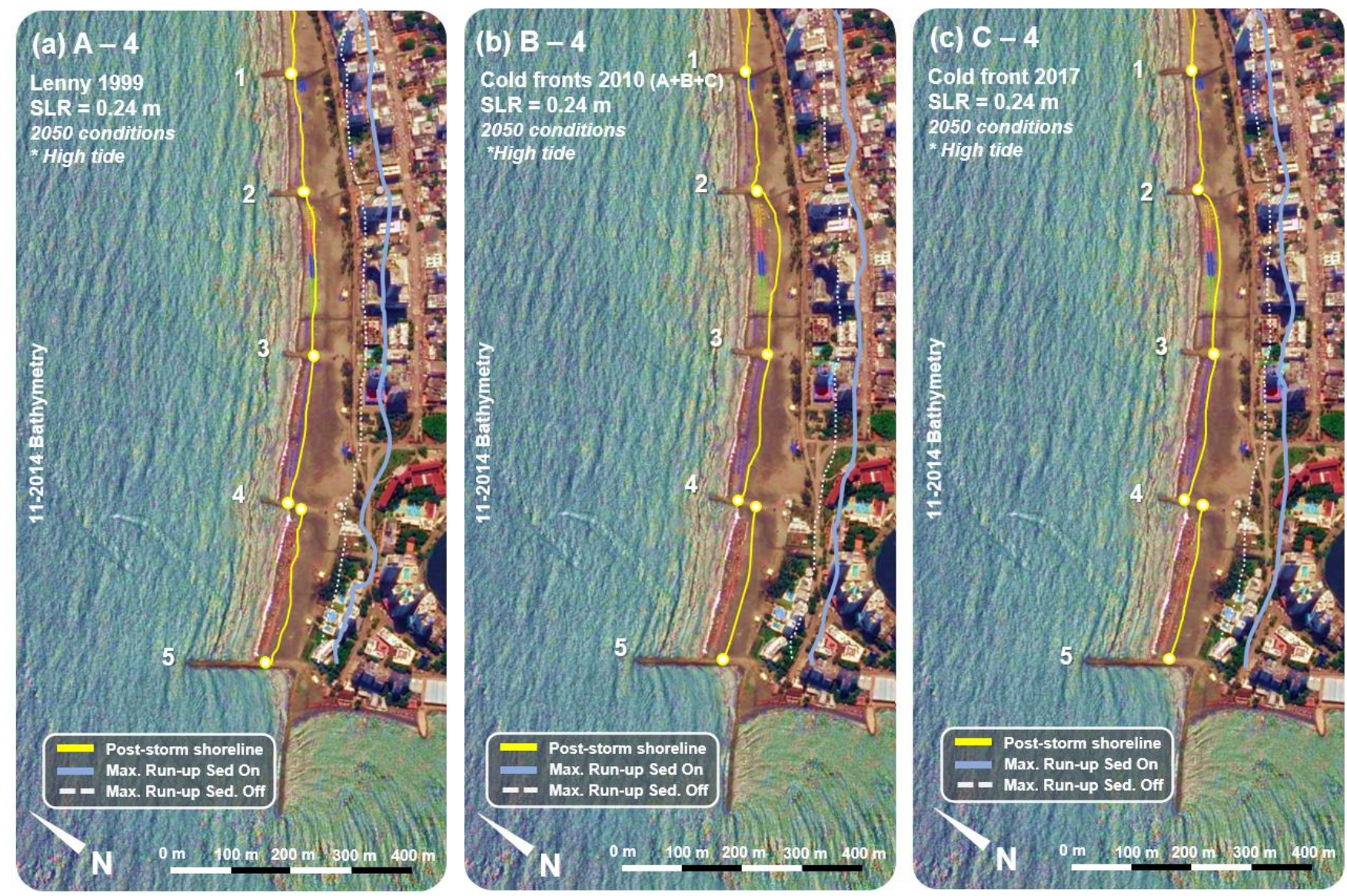

Figure 6: Maximum flood reach (with sediment transport module on and off) and post-storm shorelines simulated by XBeach including additional effect of a $+\mathbf{0 . 2 5} \mathrm{m}$ high tide for Lenny 1999 (a), 2010 cold front succession (b), and 2017 cold front (c) with different SLR conditions. Map base images retrieved from @ Google Earth and modified by the authors. 
https://doi.org/10.5194/nhess-2021-210

Preprint. Discussion started: 19 July 2021

(c) Author(s) 2021. CC BY 4.0 License.

(c) (1)

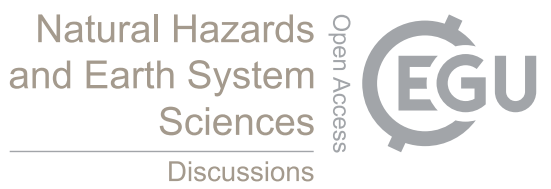

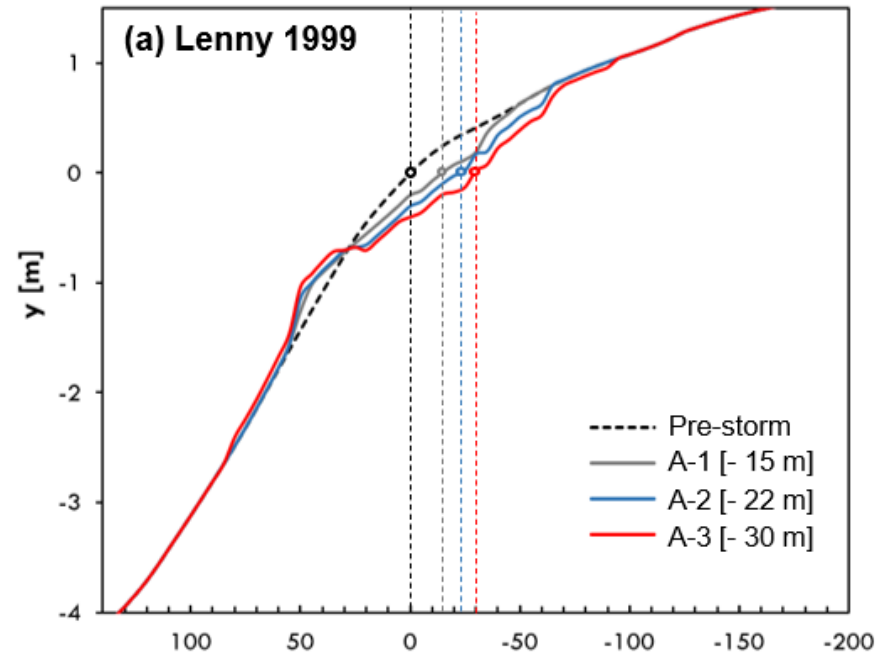

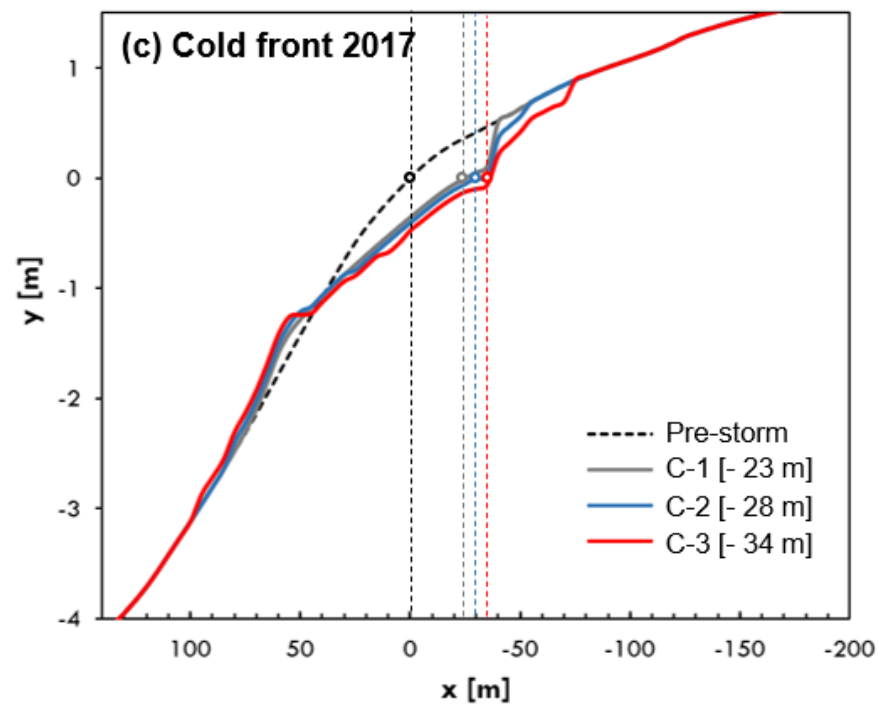

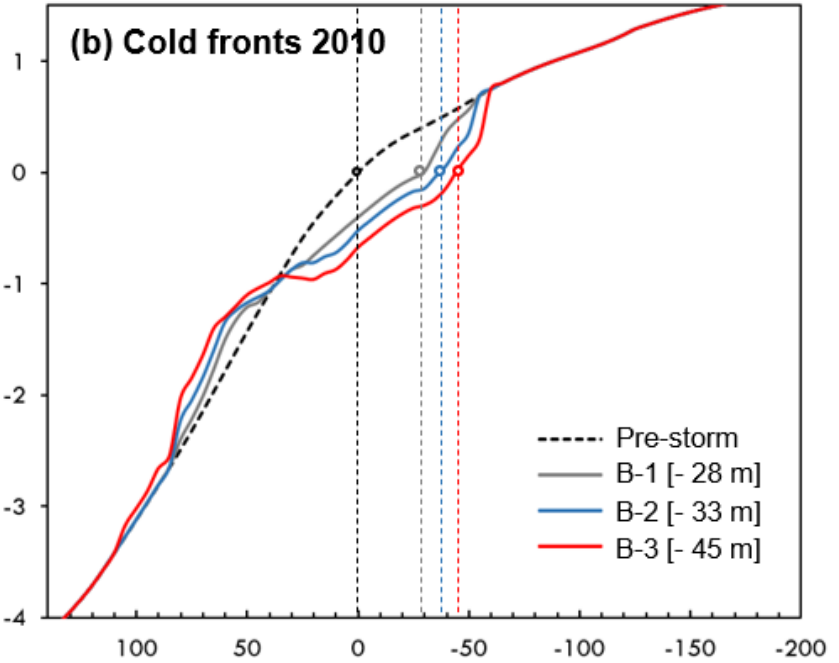

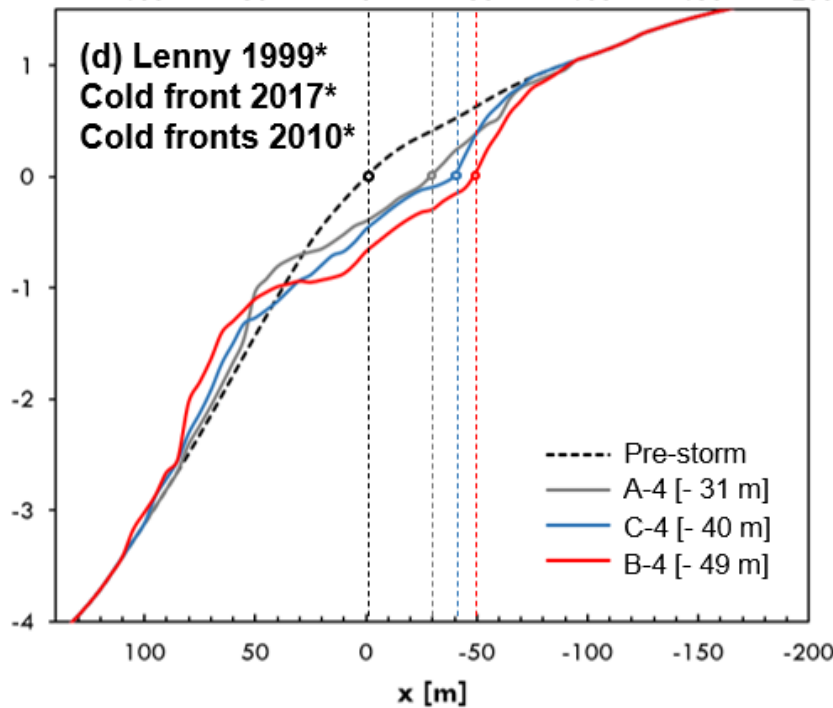

300 Figure 7: Morphologic changes of the control profile of Bocagrande for the selected case studies with calculated beach retreats. 
310 Table 6: Maximum coastline retreats, maximum flood reach (sed-on and sed-off) and maximum penetration into urban area calculated by XBeach for the case studies. *Indicates penetration into urban area considering sed-on only.

\begin{tabular}{ccccc}
\hline Case study & $\begin{array}{c}\text { Max. beach retreat } \\
{[\mathrm{m}]}\end{array}$ & $\begin{array}{c}\text { Max. inundation reach } \\
(\text { sed-on })[\mathrm{m}]\end{array}$ & $\begin{array}{c}\text { Max. inundation reach } \\
(\text { sed-off) }[\mathrm{m}]\end{array}$ & $\begin{array}{c}\text { Max. penetration in } \\
\text { urban area* }[\mathrm{m}]\end{array}$ \\
\hline A1 & 18 & 95 & 82 & 0 \\
A2 & 24 & 110 & 91 & 31 \\
A3 & 32 & 135 & 116 & 41 \\
A4 & 3.4 & 147 & 127 & 52 \\
\hline B1 & 29 & 109 & 94 & 11 \\
B2 & 36 & 145 & 113 & 50 \\
B3 & 49 & 184 & 151 & 96 \\
B4 & 52 & 199 & 164 & 105 \\
\hline C1 & 24 & 97 & 90 & 0 \\
C2 & 29 & 113 & 94 & 36 \\
C3 & 35 & 148 & 119 & 49 \\
C4 & 40 & 157 & 131 & 58 \\
\hline
\end{tabular}

\section{Discussion}

The results of the XBeach numerical model simultaneously show the morphological changes and flooding that a dissipative

315 beach with a microtidal regime such as Bocagrande Beach can experience, as caused by extreme wave events caused by cold fronts and hurricanes combined with rising mean sea levels. Evaluation of the scenarios was based on a rigorous post-storm hydrodynamic and morphodynamic calibration. As far as the authors know and checked, this methodological approach has not been followed for studying the simultaneous impact of erosion and flooding in a coastal area. This is because among the investigations reviewed and analyzed, the numerical models used lacked respective hydrodynamic and morphodynamic calibrations specific to the area studied (e.g., Annette et al., 2020). Following these ideas, the methods used in our study provide a better approximation of the real conditions of a dissipative beach with microtidal regime such as that of Bocagrande. This is because the flood studies of this beach did not consider the effects of erosion (Orejarena et al., 2019; Andrade et al., 2013). 
The erosion and flood processes cannot be decoupled because omitting erosion underestimates coastal flooding, as shown by the results of the present study and others (e.g., Alireza et al., 2020).

The extreme episode caused by successive cold fronts represents the most critical condition of coastal erosion, as occurred in 2010 (Bernal et al., 2016). This succession of extreme events generated a progressive erosion toward the coast because of a slow recovery of the beach profile. The extreme events proved efficient in substantially altering the morphology of that profile, resulting in a larger area of onshore erosion and a smaller area of offshore accretion (Figure 8), whose imbalance in crossshore sedimentary balance was caused by sediment transport longitudinal to the coast. In this sense, the post-storm profile was a consequence of the partial migration of sediments from the beachfront toward the submerged beach, forming a longitudinal bar that modified the hydrodynamic conditions of the study area.
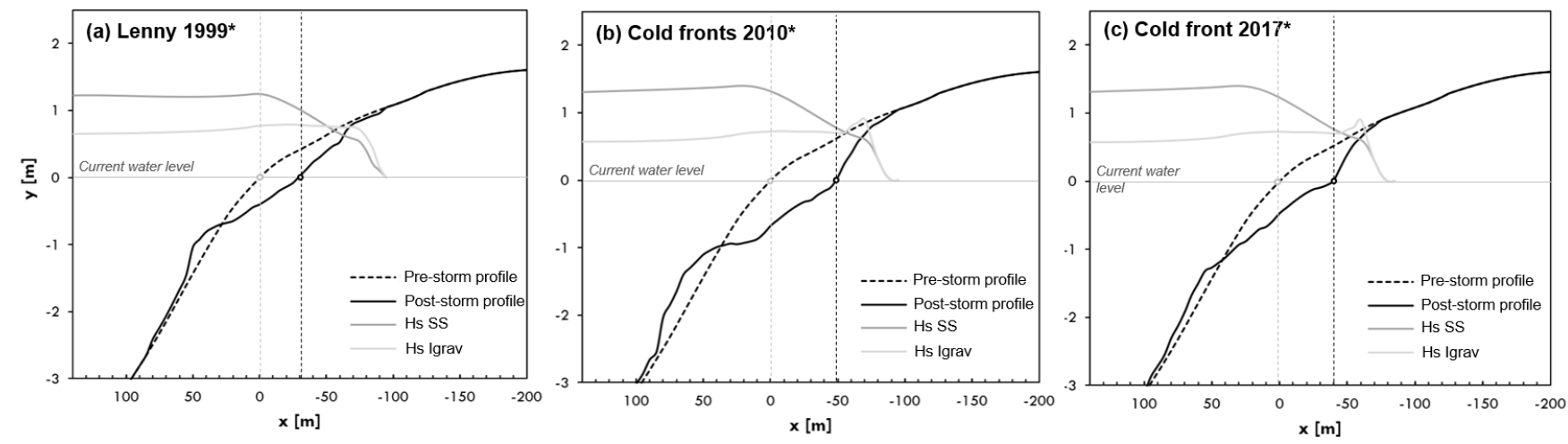

335 Figure 8: Time-averaged SS and Igrav waves and beach profiles before and after the storm for the most critical SLR condition (cases No. 4). Vertical dotted lines represent beachfront before and after the storm.

In all the cases, it is evident that the greatest impact on the coast from extreme events in terms of flooding and erosion was mainly attributable to the event duration. Although Lenny $1999\left(\mathrm{H}_{\mathrm{s} \max }=2.76 \mathrm{~m}\right.$, two days $)$ and the 2017 cold front $\left(\mathrm{H}_{\mathrm{s} \max }=\right.$ $3.53 \mathrm{~m}$, five days) had the most energetic waves, the successive cold fronts of 2010 with average $\mathrm{H}^{\mathrm{s} \max }=1.87 \mathrm{~m}$ and duration 14 days produced more erosion and flooding.

The results show SS wave energy dissipation with approach to the coast and Igrav wave energy gain due to a nonlinear transfer of energy from high to low frequencies, with the Igrav waves dominating nearshore hydrodynamics, consistent with the results of Conde et al. (2017b) (Figure 8). This result highlights the importance of involving Igrav waves in studies related to erosion 345 and flooding of the coast, because those waves increase the oscillation of the run-up, causing further erosion (de Vries et al., 2007; Kamphuis, 1996). 
https://doi.org/10.5194/nhess-2021-210

Preprint. Discussion started: 19 July 2021

(c) Author(s) 2021. CC BY 4.0 License.

(c) (1)

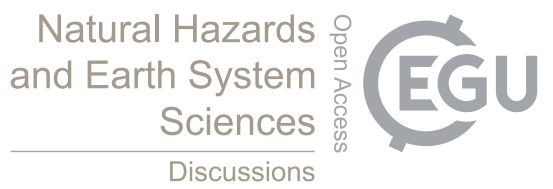

The erosion of dissipative beaches has been attributed mainly to the forcing of the Igrav regime, owing to its predominance. Many authors highlight the importance of Igrav waves in sediment transport (e.g., Holman \& Bowen, 1982; Carter et al., 1973)

350 because they have been shown efficient in suspending sediments in areas of surf and swash (Osborne \& Rooker, 1999; Aagaard \& Greenwood, 1994; Beach \& Sternberg, 1991). In such areas, suspended sediments are transported by currents invigorating coastal erosion. These effects are expected to intensify during extreme wave conditions because of increased Igrav energy (Senechal et al., 2011; Ruggiero et al.; 2004; Ruessink, 1998). However, the results of Conde et al. (2017b) for this beach show a saturation of Igrav energy in the swash zone; therefore, this is also true for the run-up. It should be noted that the 355 aforementioned studies did not consider hydrodynamic-morphodynamic interaction. Including this interaction would improve the understanding of the Igrav regime and its effects on beach erosion and flooding.

The present study also stresses the importance of sea level in erosion and flooding processes. It indicates greater flooding and retreat of the coastline as sea level increases. Historical extreme events evaluated with different SLR forecasts show the most critical situation for a greater SLR and successive extreme events. An increase in sea level allows the energy dissipation of SS waves to occur more onshore, promoting coastline retreat. This reflects the strong vulnerability of the coast of Cartagena to erosion and flooding by potential threats such as (i) extreme waves generated by cold fronts and hurricanes, and (ii) a progressive increase in sea level, whose effects on the coasts strengthen when extreme events coincide with high tides (Figure 9). 
https://doi.org/10.5194/nhess-2021-210

Preprint. Discussion started: 19 July 2021

(C) Author(s) 2021. CC BY 4.0 License.

\section{Natural Hazards and Earth System \\ Sciences \\ Discussions}

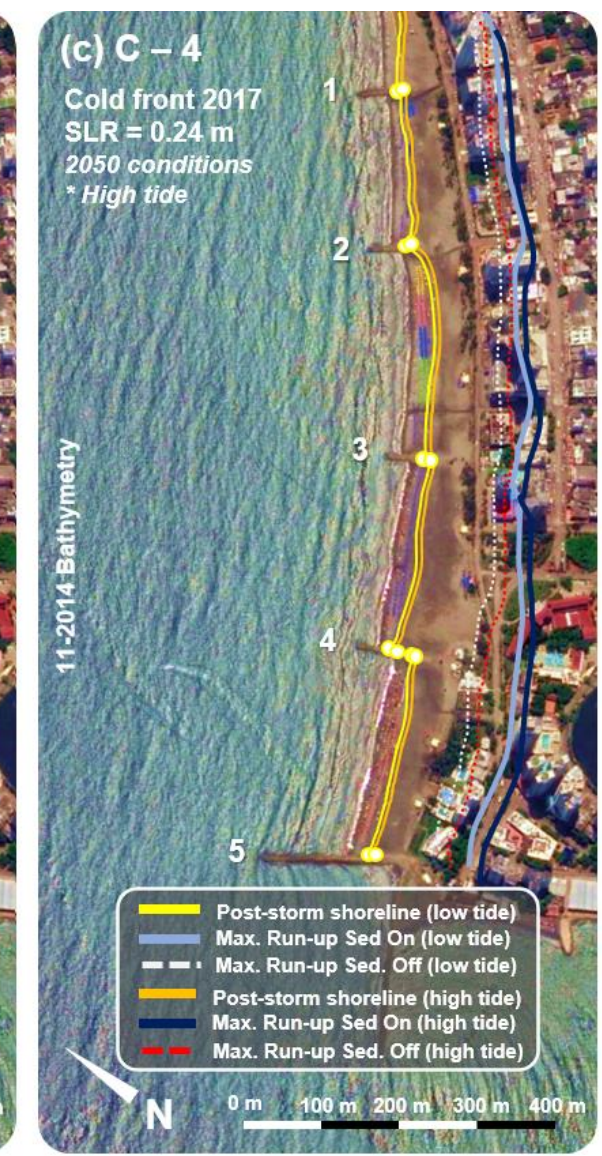

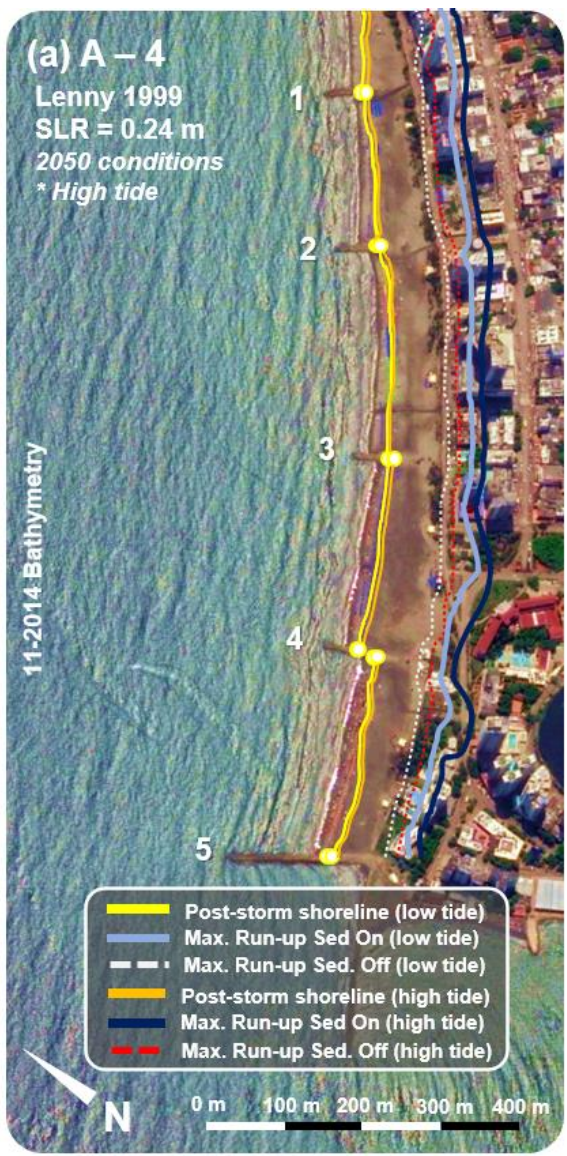

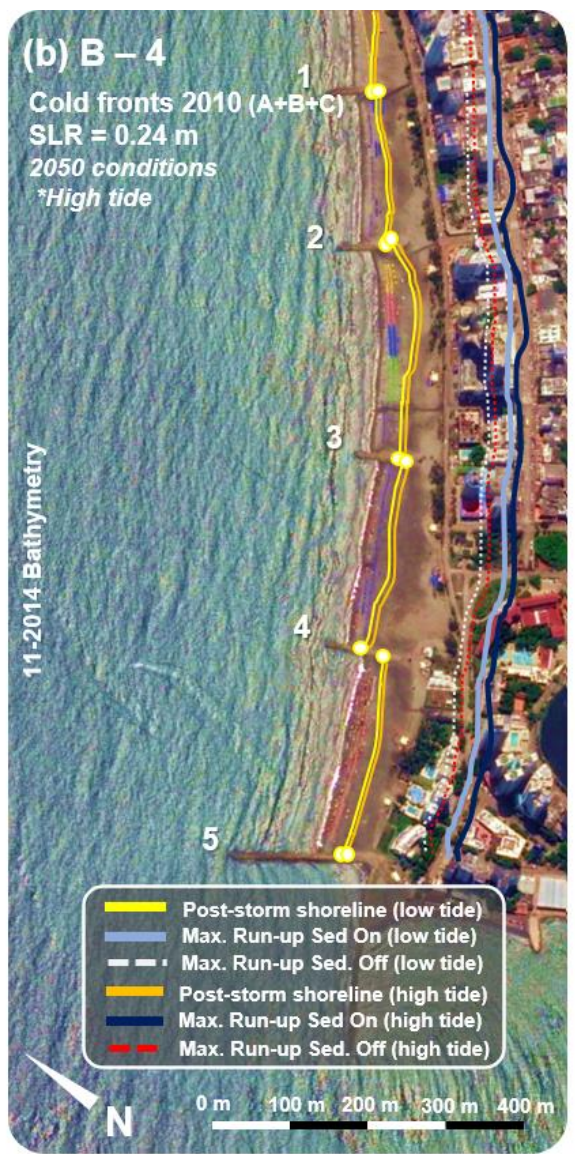

Figure 9: Maximum flood reach and post-storm shorelines simulated by XBeach at low and high tide. Map base images retrieved from (c) Google Earth and modified by the authors.

This research addresses the erosion and flooding that extreme wave events combined with SLR can cause on a dissipative microtidal beach. This type of beach is common in many parts of the world (e.g., on the coasts of the Caribbean and

Mediterranean seas and Gulf of Mexico). The results indicate the worst-case scenario for successive extreme events. This demonstrates the importance of using this type of method, because typically only individual extreme events have been evaluated. Given that the present study examined real conditions of extreme events, each of which had specific characteristics $\left(H_{s}, T_{p}, D_{m}\right.$ and duration) that make it difficult to establish relationships between waves and flooding/erosion, we suggest an assessment of the influence of the various wave parameters $\left(H_{s}, T_{p}\right.$ and $\left.D_{m}\right)$ on flooding and erosion by varying (i) the water level and (ii) the duration of the extreme event.

\section{Conclusions}

The results of this research indicate that flooding on microtidal dissipative beaches under extreme wave conditions should be approached by considering morphodynamics, because ignoring them can underestimate flooding by $\sim 15 \%$. 
A longer duration of extreme events causes greater erosion because of slow recovery of the beach profile, creating a post-storm profile with an erosion-accretion imbalance caused by the longitudinal transport of sediments toward the coast. The erosion and flood effects are intensified by SLR, resulting in the most unfavorable condition when extreme events are contemporaneous with high tides.

Individual extreme events are typically evaluated to establish the threat to coastal zones, but the results of the present study suggest the evaluation of successive extreme event scenarios, because they represent the worst erosion and flooding scenario.

\section{References}

Aagaard, T., \& Greenwood, B. (1994). Suspended sediment transport and the role of infragravity waves in a barred surf zone. Marine Geology, 118(1-2), 23-48. https://doi.org/10.1016/0025-3227(94)90111-2

Andrade, C. A., Thomas, Y. F., Lerma, A. N., Durand, P., \& Anselme, B. (2013). Coastal Flooding Hazard Related to Swell Events in Cartagena de Indias, Colombia. Journal of Coastal Research, 290(5), 1126-1136. https://doi.org/10.2112/JCOASTRES-D-12-00028.1

Beach, R.A. \& Sternberg, R.W., 1991. Infragravity Driven Suspended Sediment Transport in the Swash, Inner and Outer-Surf Zone. Proceedings Coastal Sediments, 91, New York, ASCE, pp. 114-128.

Bernal, G., Osorio, A. F., Urrego, L., Peláez, D., Molina, E., Zea, S., Montoya, R. D., \& Villegas, N. (2016). Occurrence of energetic extreme oceanic events in the Colombian Caribbean coasts and some approaches to assess their impact on ecosystems. Journal of Marine Systems, 164, 85-100. https://doi.org/10.1016/j.jmarsys.2016.08.007

Bertin, X., Li, K., Roland, A., Zhang, Y. J., Breilh, J. F., \& Chaumillon, E. (2014). A modeling-based analysis of the flooding associated with Xynthia, central Bay of Biscay. Coastal Engineering, 94(212), 80-89. https://doi.org/10.1016/j.coastaleng.2014.08.013

Booij, N., Ris, R. C., \& Holthuijsen, L. H. (1999). A third-generation wave model for coastal regions: 1. Model description and validation. Journal of Geophysical Research: Oceans, 104(C4), 7649-7666. https://doi.org/10.1029/98JC02622

Carlos, J., Royero, O., López Martínez, F., Díaz Estrada, E., Felipe, L., \& Arango, B. (2008). Incluyendo a la Isla Andrés. In Revista Colombiana de Física (Vol. 40, Issue 2). http://weather.unisys.com/hurricane/atlantic/index.html.

Carter, T. G., Liu, P. L. F. \& Mei, C. C. 1973 Mass transport by waves and offshore sand bed-forms. J. Waterw. Harbors Coastal Eng. Div. 99, 165-183.

405 Chawla, A., Spindler, D. M., \& Tolman, H. L. (2013). Validation of a thirty year wave hindcast using the Climate Forecast System Reanalysis winds. Ocean Modelling, 70, 189-206. https://doi.org/10.1016/j.ocemod.2012.07.005

Christensen, B.B.; Drønen, N.; Klagenberg, P.; Jensen, J.; Deigaard, R.; Sørensen, P. Multiscale modelling of coastal flooding. In Proceedings of 7 th International Conference for Coastal Dynamics, Arcachon Convention.

Ciavola, P.; Ferreira, O.; Haerens, P.; Van Koningsveld, M.; Armaroli, C. Storm impacts along European coastlines. Part 2: 410 Lessons learned from the MICORE project. Environ. Sci. Policy 2011, 14, 924-933.

Conde-Frias, M., Otero, L., Restrepo, J. C., Ortiz, J. C., Ruiz, J., \& Osorio, A. F. (2017). Swash Oscillations in a Microtidal Dissipative Beach. Journal of Coastal Research, 336(6), 1408-1422. https://doi.org/10.2112/JCOASTRES-D-16-00147.1 
Cueto, J., \& Otero, L. (2020). Morphodynamic response to extreme wave events of microtidal dissipative and reflective beaches. Applied Ocean Research, 101, 102283. https://doi.org/10.1016/j.apor.2020.102283

415 de Santiago, I., Morichon, D., Abadie, S., Reniers, A. J. H. M., \& Liria, P. (2017). A comparative study of models to predict storm impact on beaches. Natural Hazards, 87(2), 843-865. https://doi.org/10.1007/s11069-017-2830-6

de Vries, J. S. M. Van Thiel, van Gent, M. R. A., Walstra, D. J. R. \& Reniers, A. J. H. M. 2007 Analysis of dune erosion processes in large-scale flume experiments. Coast. Eng. 55, 1028-1040.

Dissanayake, P., Brown, J., \& Karunarathna, H. (2014). Modelling storm-induced beach/dune evolution: Sefton coast,

Liverpool Bay, UK. Marine Geology, 357, 225-242. https://doi.org/10.1016/j.margeo.2014.07.013

Elsayed, S., \& Oumeraci, H. (2016). Combined Modelling of Coastal Barrier Breaching and Induced Flood Propagation Using XBeach. Hydrology, 3(4), 32. https://doi.org/10.3390/hydrology3040032

Enríquez, A. R., Marcos, M., Falqués, A., \& Roelvink, D. (2019). Assessing beach and dune erosion and vulnerability under sea level rise: A Case study in the Mediterranean Sea. Frontiers in Marine Science, 6(JAN). https://doi.org/10.3389/fmars.2019.00004

Fiedler, J. W., Smit, P. B., Brodie, K. L., McNinch, J., \& Guza, R. T. (2018). Numerical modeling of wave runup on steep and mildly sloping natural beaches. Coastal Engineering, 131, 106-113. https://doi.org/10.1016/j.coastaleng.2017.09.004

Gharagozlou, A., Dietrich, J. C., Karanci, A., Luettich, R. A., \& Overton, M. F. (2020). Storm-driven erosion and inundation of barrier islands from dune-to region-scales. Coastal Engineering, 158. https://doi.org/10.1016/j.coastaleng.2020.103674

430 Grilli, A. R., Westcott, G., Grilli, S. T., Spaulding, M. L., Shi, F., \& Kirby, J. T. (2020). Assessing coastal hazard from extreme storms with a phase resolving wave model: Case study of Narragansett, RI, USA. Coastal Engineering, 160. https://doi.org/10.1016/j.coastaleng.2020.103735

Guimarães, P. V., Farina, L., Toldo, E., Diaz-Hernandez, G., \& Akhmatskaya, E. (2015). Numerical simulation of extreme wave runup during storm events in Tramandaí Beach, Rio Grande do Sul, Brazil. Coastal Engineering, 95, 171-180. https://doi.org/10.1016/j.coastaleng.2014.10.008

Harley, M. D., Turner, I. L., Kinsela, M. A., \& Hanslow, D. J. (2017). Observations of beach recovery in SE Australia following the June 2016 east coast low Design of Coastal Protection on Reef Mediated Coastlines View project Beaches in Estuaries and Bays View project. https://www.researchgate.net/publication/318011521

He, Z., Hu, P., Zhao, L., Wu, G., \& Pähtz, T. (2015). Modeling of breaching due to overtopping flow and waves based on coupled flow and sediment transport. Water (Switzerland), 7(8), 4283-4304. https://doi.org/10.3390/w7084283

Holman, R. A., \& Bowen, A. J. (1982). Bars, bumps, and holes: Models for the generation of complex beach topography. Journal of Geophysical Research, 87(C1), 457. https://doi.org/10.1029/JC087iC01p00457

Jiménez, J. A., Sanuy, M., Ballesteros, C., \& Valdemoro, H. I. (2018). The Tordera Delta, a hotspot to storm impacts in the coast northwards of Barcelona (NW Mediterranean). Coastal Engineering, 134, 148-158. https://doi.org/10.1016/j.coastaleng.2017.08.012

KAMPHUIS, J. W. (1996). PHYSICAL MODELING OF COASTAL PROCESSES (pp. 79-114). https://doi.org/10.1142/9789812797575_0002

Kron, W. (2013). Coasts: The high-risk areas of the world. Natural Hazards, 66(3), 1363-1382. https://doi.org/10.1007/s11069-012-0215-4 
https://doi.org/10.5194/nhess-2021-210

Preprint. Discussion started: 19 July 2021

(c) Author(s) 2021. CC BY 4.0 License.

Natural Hazards

and Earth System

Sciences

Discussions

450 Luijendijk, A. P., Ranasinghe, R., de Schipper, M. A., Huisman, B. A., Swinkels, C. M., Walstra, D. J. R., \& Stive, M. J. F. (2017). The initial morphological response of the Sand Engine: A process-based modelling study. Coastal Engineering, 119, 1-14. https://doi.org/10.1016/j.coastaleng.2016.09.005

M. Vega, Comparación de metodologías de refinamiento de escala de reanálisis de oleaje [master's thesis]. Barranquilla, Colombia: Universidad del Norte 2017.http://manglar.uninorte.edu.co/handle/10584/7943\#page=1

455 Mario, C. F., Luis, O., Restrepo, J. C., \& Juan, C. O. (2017). Experimental analysis of infragravity waves in two eroded microtidal beaches. Acta Oceanologica Sinica, 36(5), 31-43. https://doi.org/10.1007/s13131-017-1054-7

McCall, R. T., van Thiel de Vries, J. S. M., Plant, N. G., van Dongeren, A. R., Roelvink, J. A., Thompson, D. M., \& Reniers, A. J. H. M. (2010). Two-dimensional time dependent hurricane overwash and erosion modeling at Santa Rosa Island. Coastal Engineering, 57(7), 668-683. https://doi.org/10.1016/j.coastaleng.2010.02.006

460 Medellín, G., Brinkkemper, J. A., Torres-Freyermuth, A., Appendini, C. M., Mendoza, E. T., \& Salles, P. (2016). Run-up parameterization and beach vulnerability assessment on a barrier island: A downscaling approach. Natural Hazards and Earth System Sciences, 16(1), 167-180. https://doi.org/10.5194/nhess-16-167-2016

Nederhoff, C. M., Lodder, Q. J., Boers, M., den Bieman, J. P., \& Miller, J. K. (2015, July). MODELING THE EFFECTS OF HARD STRUCTURES ON DUNE EROSION AND OVERWASH. https://doi.org/10.1142/9789814689977_0219

465 Nicolae Lerma, A., Pedreros, R., Robinet, A., \& Sénéchal, N. (2017). Simulating wave setup and runup during storm conditions on a complex barred beach. Coastal Engineering, 123, 29-41. https://doi.org/10.1016/j.coastaleng.2017.01.011

Orejarena-Rondón, A. F., Sayol, J. M., Marcos, M., Otero, L., Restrepo, J. C., Hernández-Carrasco, I., \& Orfila, A. (2019). Coastal Impacts Driven by Sea-Level Rise in Cartagena de Indias. Frontiers in Marine Science, 6, 614. https://doi.org/10.3389/fmars.2019.00614

470 Ortíz Royero, J. C. (2007). Huracanes y tormentas tropicales en el mar Caribe colombiano desde 1900. Boletín Científico CIOH, 25(25), 54-60. https://doi.org/10.26640/22159045.162

Ortiz Royero, J. C. (2009). Aplicación de un modelo paramétrico de vientos y un modelo de oleaje espectral para el estudio del oleaje máximo generado por el huracán Lenny en las costas del Caribe colombiano en 1999. Boletín Científico CIOH, 27, 29-36. https://doi.org/10.26640/01200542.27.29_36

475 Ortiz, J. C., Salcedo, B., \& Otero, L. J. (2014). Investigating the Collapse of the Puerto Colombia Pier (Colombian Caribbean Coast) in March 2009: Methodology for the Reconstruction of Extreme Events and the Evaluation of their Impact on the Coastal Infrastructure. Journal of Coastal Research, 294(2), 291-300. https://doi.org/10.2112/JCOASTRES-D-12-00062.1

Ortiz-Royero, J. C., Otero, L. J., Restrepo, J. C., Ruiz, J., \& Cadena, M. (2013). Cold fronts in the Colombian Caribbean Sea and their relationship to extreme wave events. Natural Hazards and Earth System Sciences, 13(11), $2797-2804$. https://doi.org/10.5194/nhess-13-2797-2013

Osborne, P., \& Rooker, G. (1999). Sand Re-Suspension Events in a High Energy Infragravity Swash Zone on JSTOR. Journal of Coastal Research. https://www.jstor.org/stable/4298916?seq=1

Otero, L. J., Ortiz-Royero, J. C., Ruiz-Merchan, J. K., Higgins, A. E., \& Henriquez, S. A. (2016). Storms or cold fronts: What is really responsible for the extreme waves regime in the Colombian Caribbean coastal region? Natural Hazards and Earth System Sciences, 16(2), 391-401. https://doi.org/10.5194/nhess-16-391-2016

Pérez, R. A., Ortiz, R. J. C., Bejarano, A. L. F., Otero, D. L., Restrepo, L. J. C., \& Franco, A. A. (2018). Sea breeze in the Colombian Caribbean coast. Atmosfera, 31(4), 389-406. https://doi.org/10.20937/ATM.2018.31.04.06 
Plomaritis, T. A., Ferreira, Ó., \& Costas, S. (2018). Regional assessment of storm related overwash and breaching hazards on coastal barriers. Coastal Engineering, 134, 124-133. https://doi.org/10.1016/j.coastaleng.2017.09.003

Poveda, G. (n.d.). LA HIDROCLIMATOLOGÍA DE COLOMBIA: UNA SÍNTESIS DESDE LA ESCALA INTERDECADAL HASTA LA ESCALA DIURNA por CIENCIAS DE LA TIERRA.

Ranasinghe, R., Swinkels, C., Luijendijk, A., Roelvink, D., Bosboom, J., Stive, M., \& Walstra, D. J. (2011). Morphodynamic upscaling with the MORFAC approach: Dependencies and sensitivities. Coastal Engineering, 58(8), 806-811. https://doi.org/10.1016/j.coastaleng.2011.03.010

Rangel-Buitrago, N. G., Anfuso, G., \& Williams, A. T. (2015). Coastal erosion along the Caribbean coast of Colombia: Magnitudes, causes and management. Ocean and Coastal Management, 114, 129-144. https://doi.org/10.1016/j.ocecoaman.2015.06.024

Restrepo, J. C., Otero, L., Casas, A. C., Henao, A., \& Gutiérrez, J. (2012). Shoreline changes between 1954 and 2007 in the marine protected area of the Rosario Island Archipelago (Caribbean of Colombia). Ocean and Coastal Management, 69, 133142. https://doi.org/10.1016/j.ocecoaman.2012.07.027

Restrepo, J. C., Schrottke, K., Traini, C., Ortíz, J. C., Orejarena, A., Otero, L., Higgins, A., \& Marriaga, L. (2016). Sediment Transport and Geomorphological Change in a High-Discharge Tropical Delta (Magdalena River, Colombia): Insights from a Period of Intense Change and Human Intervention (1990-2010). Journal of Coastal Research, 319(3), 575-589. https://doi.org/10.2112/JCOASTRES-D-14-00263.1

505 Roelvink, D., Reniers, A., van Dongeren, A., van Thiel de Vries, J., McCall, R., \& Lescinski, J. (2009). Modelling storm impacts on beaches, dunes and barrier islands. Coastal Engineering, 56(11-12), 1133-1152. https://doi.org/10.1016/j.coastaleng.2009.08.006

Ruessink, B. G., Kleinhans, M. G., \& van den Beukel, P. G. L. (1998). Observations of swash under highly dissipative conditions. Journal of Geophysical Research: Oceans, 103(C2), 3111-3118. https://doi.org/10.1029/97JC02791

510 Ruggiero, P. (2004). Wave run-up on a high-energy dissipative beach. Journal of Geophysical Research, 109(C6), C06025. https://doi.org/10.1029/2003JC002160

Ruju, A., Lara, J. L., \& Losada, I. J. (2014). Numerical analysis of run-up oscillations under dissipative conditions. Coastal Engineering, 86, 45-56. https://doi.org/10.1016/j.coastaleng.2014.01.010

Sanuy, \& Jiménez. (2019). Sensitivity of Storm-Induced Hazards in a Highly Curvilinear Coastline to Changing Storm

Directions. The Tordera Delta Case (NW Mediterranean). Water, 11(4), 747. https://doi.org/10.3390/w11040747

Schambach, L., Grilli, A. R., Grilli, S. T., Hashemi, M. R., \& King, J. W. (2018). Assessing the impact of extreme storms on barrier beaches along the Atlantic coastline: Application to the southern Rhode Island coast. Coastal Engineering, 133, $26-42$. https://doi.org/10.1016/j.coastaleng.2017.12.004

Senechal, N., Coco, G., Bryan, K. R., \& Holman, R. A. (2011). Wave runup during extreme storm conditions. Journal of Geophysical Research, 116(C7), C07032. https://doi.org/10.1029/2010JC006819

Sills, G. L., Asce, M., Vroman, ; N D, Wahl, ; R E, \& Schwanz, N. T. (2008). Overview of New Orleans Levee Failures: Lessons Learned and Their Impact on National Levee Design and Assessment. J. Geotech. Geoenviron. Eng., 556-565. https://doi.org/10.1061/ASCE1090-02412008134:5556

Stockdon, H. F., Thompson, D. M., Plant, N. G., \& Long, J. W. (2014). Evaluation of wave runup predictions from numerical and parametric models. Coastal Engineering, 92, 1-11. https://doi.org/10.1016/j.coastaleng.2014.06.004 
https://doi.org/10.5194/nhess-2021-210

Preprint. Discussion started: 19 July 2021

(c) Author(s) 2021. CC BY 4.0 License.

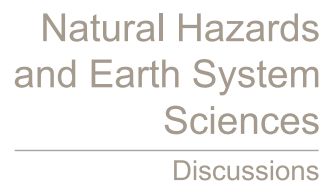

(c) (1)

Discussions

Torres, R. R., \& Tsimplis, M. N. (2012). Seasonal sea level cycle in the Caribbean Sea. Journal of Geophysical Research: Oceans, 117(C7), n/a-n/a. https://doi.org/10.1029/2012JC008159

van Dongeren, A., Ciavola, P., Martinez, G., Viavattene, C., Bogaard, T., Ferreira, O., Higgins, R., \& McCall, R. (2018). Introduction to RISC-KIT: Resilience-increasing strategies for coasts. Coastal Engineering, 134, 2-9. https://doi.org/10.1016/j.coastaleng.2017.10.007

van Gent, M. R. A., van Thiel de Vries, J. S. M., Coeveld, E. M., de Vroeg, J. H., \& van de Graaff, J. (2008). Large-scale dune erosion tests to study the influence of wave periods. Coastal Engineering, 55(12), 1041-1051. https://doi.org/10.1016/j.coastaleng.2008.04.003

van Rijn, L. C., Walstra, D. J. R., Grasmeijer, B., Sutherland, J., Pan, S., \& Sierra, J. P. (n.d.). The predictability of cross-shore 535 bed evolution of sandy beaches at the time scale of storms and seasons using process-based Profile models. www.elsevier.com/locate/coastaleng

Wu, W., Altinakar, M., Al-Riffai, M., \& Bergman, N. (2011). Earthen Embankment Breaching. Journal of Hydraulic Engineering, 137(12), 1549-1564. https://doi.org/10.1061/(ASCE)HY.1943-7900.0000498 